\title{
The influence of teachers' leadership and classroom climate on students' achievement motivation
}

\author{
Fory A. Naway ${ }^{1}$, Ikhfan Haris ${ }^{2}$, Yulin Nue $^{3}$ \\ \{forynawai@ung.ac.id ${ }^{1}$ \} \\ ${ }^{1,2,3}$ Department of Education Management, Faculty of Education, Universitas Negeri Gorontalo, \\ Gorontalo, Indonesia
}

\begin{abstract}
The objective of this present study is to explore the correlation of teachers' leadership in learning process and classroom climate towards students' achievement motivation in selected junior high schools, Limboto Sub-district, Gorontalo Regency. This quantitative study employed a correlational method. The population were 400 grade VIII students; 80 students were selected as the sample using proportional random sampling method. Data analysis methods comprised a validity test, instrument reliability test and data normality test, as well as partial and simultaneous correlational test. The results reveal that: Teachers' leadership in learning process positively and significantly contributes to the students' achievement motivation in the research site. This indicates that the better the teachers' leadership, the better and the higher the students' achievement motivation. Classroom climate positively and significantly contributes to the students' achievement motivation in the research site. In other words, a supportive climate of the classroom increases students' motivation. Both teachers' leadership in the learning process and classroom climate positively and significantly contributes to the students' achievement motivation in the research site, meaning that if both of the aspects as mentioned earlier are considered high, the students are certainly more motivated to attain successful goals. This research proposes several recommendations. First, school principals are encouraged to improve teachers' leadership in the learning process through supervision to increase students' motivation. Second, teachers need to improve their leadership in the learning process. This is to encourage students to keep doing their best. Third, students should increase their motivation through positive actions during classroom learning.
\end{abstract}

Keywords: Teachers' Leadership, Classroom Climate, Learning Achievement

\section{Introduction}

Internal and external factors are crucial in fostering students' achievement motivation. Some examples of aspects that come from oneself, the internal factors, are students' feeling of competing with others if their friends perform better than them. On the other hand, external factors refer to outside influences that can impact students' learning achievement. One of the examples of external factors is a social environment, including human's interpersonal relationship, in both direct and indirect form of communication. A school environment is among the social environment. This environment consisted of several elements other than students, such as school principals. Such elements contribute to the process and result of a student's learning outcome. 
Students are urged to possess achievement motivation; this is to foster the competitiveness among the students during learning. The level of students' motivation achievement is affected by some factors, such as their teachers.

Increasing students' motivation requires a supportive classroom climate. A classroom climate refers to a classroom environment or characteristics that differ a situation in a class with another despite the similarity of the classroom in terms of physical appearance.

Achievement motivation is not only determined by classroom climates but also teachers' leadership in the learning process. Such leadership is a leadership style focusing on all components of learning, e.g., curriculum, teaching and learning processes, assessment (of learning outcome), teachers' assessment and development in digital era, optimum learning services, and school community development. A teacher is the most crucial component that determines the success in learning. This is the reason why teachers play a major role in such processes. A teacher is responsible for planning, implementing, and evaluating learning.

A preliminary observation in several junior high schools in Limboto Sub-district, Gorontalo Regency reveals that the students' achievement motivation is considered low. This is seen from (1) students' lack of enthusiasm in learning, (2) poor motivation, (3) lack of competitiveness in both academic and non-academic setting, and (4) lack of targets or objectives. Such an issue blames the inability of teachers in terms of their leadership during the teaching and learning process. As a result, the teachers are unable to cultivate students' learning interest and engagement in learning; thus, the teachers fail to foster the students' competitiveness. Another poor leadership in the learning process is that a failure in conceptualizing an engaging, conducive classroom for their students. Therefore, teachers' leadership in the learning process must be improved to ensure that the learning objectives are met as the students are highly motivated to attain successful goals.

From the above background, the researcher is urged to conduct a study entitled "The Influence of Teachers' Leadership and Classroom Climateon Students' Achievement Motivation.

Grounding from the above background, the problem statements of this research are as follows:

1. Is there any correlation between the teachers' leadership in the learning process and grade VIII students' achievement motivation in all junior high schools within Limboto Sub-district?

2. Is there any correlation between the classroom climate and grade VIII students' achievement motivation in all junior high schools within Limboto Sub-district?

3. Do the teachers' leadership in the learning process and the classroom climate influence grade VIII students' achievement motivation in all junior high schools within Limboto Sub-district?

The purposes of this research are as follows:

1. To find out the correlation between the teachers' leadership in the learning process and grade VIII students' achievement motivation in all junior high schools within Limboto Sub-district.

2. To find out the correlation between the classroom climate and grade VIII students' achievement motivation in all junior high schools within Limboto Sub-district.

3. To explore the influence of teachers' leadership in the learning process and the classroom climate on grade VIII students' achievement motivation in all junior high schools within Limboto Sub-district.

The significancesof research are as follows: 
1. This research can function as the source of information for schools on how to improve teachers' leadership in the learning process and how to promote a classroom climate that can foster students' achievement motivation.

2. This research provides teachers with in-depth information on leadership in the learning process.

3. This research can serve as a reference for further studies.

\section{Theoretical Framework}

Murray (as cited in Winkel, 2004, p.29) defines the term achievement motivation as a driving force that leads students to attain a successful goal in learning for the individual's sense of achievement. McClelland, a pioneer in the study of achievement motivation and its developmental measurement, provides a narrower definition of motivation achievement as the efforts to succeed in a competition measured by a particular superiority. The measurement can refer to the individual's past achievement or other people's achievement (Haditono, 2009, p.8).

According to McClelland (2007, p.40), achievement motivation refers to the way an individual pursues success in competition; the benchmark of success can be the achievement of oneself or other people. Lindgren (2006, p.67) shares the same thought on defining the term achievement motivation as an inner driving force of an individual related to achievement; this involves the waya person controls, manipulates and manages the social or physical environment, copes with challenges, and maintaining quality works. Such force also refers to competing with others to surpass the previous achievement of oneself and other people's accomplishment.

From the above discussion, it can be said that achievement motivation is a driving force that leads someone to accomplish his or her goal; the category of success is measured by the superiority of oneself or other people.

Santrork (2003: p.103) opines that achievement motivation is a desire to accomplish a certain goal to pursue success. Further, Gagne and Barliner (2005, p.77) add that achievement motivation is the way an individual gives the best of his or herself for their sense of achievement.

In conclusion, achievement motivation is the driving force of an individual that correlates with the behavior of doing the best of the person and even beyond what they can do compared to the previous achievement. This is intended to attain a particular result as the person desires with other people or the individual's achievement serves as the benchmark of the success.

Heekhausen (2007, p.54) argues that achievement motivation is the way a person strives to improve self capacities the best the person can in every activity. A particular measurement is used to compare the result of the effort despite the possibility of success and failure while performing the activities. Heekhausen further adds that achievement motivation represents a motive that drives an individual to succeed in competition with several standards of excellence.Such standards are used as a benchmark of self-achievement in the past which ensures the validity of the achievement in a competition.

McClelland (as cited in Usman, 2008, p.260) mentions several characteristics of a person with high achievement motivation.Those are (1) be responsible for all actions, committed to self-career and future, and not blaming others for self-failure; (2) trying to find feedback on self-actions and willing to listen to the opinions of others as input to improve self-capability; (3) dare to take risks more than others and performing the best; (4) trying to do something innovatively and creatively and able to actualize ideas, and avoiding systems that limit 
positive movements; (5) time management and avoiding procrastination, and; (6) hardworking and proud of self-achievement.

A highly-motivated individual often strives to be more than other people. People of this type, according to Danim (2012, p.33) possesses several traits, such as (1) dare to take moderate risks. A highly-motivated person does not reluctant to take risks. However, such a person has innovative solutions to problems. This individual calculates every risk and chooses the one with a high possibility of success. (2) The highly-motivated individual immediately asks for immediate feedback on their performance. The feedbacks, comprising of the weaknesses and strengths of the individual, are useful to attain higher goals. (3) The highly motivated individual calculates every success opportunity thoroughly. This person prioritizes task achievement rather than the possible reward as the individual believes that achievement means satisfaction (intrinsically) for the person. (4) Another characteristic of a highlymotivated individual is committed to working. Such a person does not consider his or her work as a burden. In addition, this individual does not procrastinate. In terms of interpersonal relationship in a workplace, such an individual is friendly, realistic, and prioritizes individual's ability.

Highly-motivated individuals, in terms of achievement motivation, are recognized for several characteristics. Mc Clelland (as cited in Wahidin, 2001) mentions that those involve (1) Having the desire to have a healthy competition with oneself and other people; (2) Having the desire to perform better; (3) Thinking realistically, be aware of self-strengths and weaknesses; (4) Having personal responsibility; (5) Being able to create breakthrough; (6) Thinking strategically in the long term, (7) Continuously utilizing feedback for improvement.

Soulworth (2002) explains that leadership in learning is paying great attention to teaching and learning, including the pedagogic of teacher professionals based on student development. Bush and Glover (2003) add that such leadership focuses on teaching and learning, as well as teacher's behavior in teaching. The influence of leadership is directed to the learning process of the student by the teacher. The process mentioned earlier shows such an emphasis.

Teacher's leadership refers to the ability of a teacher to influence, manage, and guide the students in the learning process. This functions to meet the learning objective(s). Said (2007:202) points out that leadership, as a part of a leader, cannot be actualized without the involvement of subordinates. This signifies that a group is unable to reach the common goal of its members effectively unless the group is led by a trusted leader that brings the group to the goal.

The above discussion concludes that teacher's leadership in learning process focuses on components of learning, including teaching-learning processes, learning evaluation, and other processes related to the student-teacher interaction during learning to accomplish the desired objectives.

Anwar (1990, p.4) asserts that in learning, a teacher as a leader in the class is responsible for guiding and influencing students to do activities efficiently for a conducive learning atmosphere. This signifies the importance of the leadership of the teacher in the class. Good leadership also allows the teacher to direct the students' attitude and behavior in addition to influencing the students to learn the lessons at school. Teacher-student interaction must also be well implemented to actualize a better learning condition by which it motivates the students to participate during the class actively. In other words, the success of the students in the learning process is determined by their activities and the roles of the teacher in guiding, encouraging, and directing the students to engage in every process of learning.

In conclusion, the teacher's leadership in learning encompasses all processes of learning activities. These processes associate with learning objectives that both teacher and students 
aim for and thus resulting in effective learning activities. That being said, the teacher is urged to be creative in improving students' learning motivation and ensuring the academic success of the students. Sanjaya (2006, p.29) mentions several approaches to increase motivation; those are (1) clearly stating the objectives, (2) stimulating students' interests, (3) promoting fun learning atmosphere, (4) praising students for their success, and (5) creating a competitive and co-operative climate in the class.

According to Mulyono (2009, p.91) names two types of teacher's leadership in learning, i.e., (1) actualization and management of optimum learning climates, and (2) skills related to the management of optimum learning condition. Skills in actualizing and managing optimum learning climates are further divided into six, involving (1) showing responsive behavior in the class, (2) dividing attention in terms of visual and verbal, (3) focusing the attention of students' group by preparing the students during learning, (4) providing clear instructions, (5) warning the students wisely, (6) reinforcing students if needed.

Mulyasa (2009, p.91-92) mentions three skills related to the management of optimum learning condition, such as (1) behavior modification, (2) management of the group, and (3) finding and coping with problematic behaviors. The modification of behavior comprises three major aspects, i.e., (1) teaching new behaviors by giving an example of habitual actions, (2) improving positive behaviors through reinforcement, and (3) breaking bad habits through punishment. According to Djamrah and Zain (2006, p.2), good leadership of teacher in learning results is in a positive teaching-learning interaction. This also ensures the accomplishment of learning goals without any problems. Regarding this, Suryosubroto (2002) names several factors associated with influencing teacher, namely: (1) Personality. This involves behaviors, authority, character, and other related factors that affect interaction. (2) Mastery of lesson. The success of interaction is determined by the way the teacher comprehend the content of the lesson. (3) Comprehending the class. This aspect determines the interaction in the process of education. The chaotic classroom is due to teacher's poor comprehension of the class. (4) Communication style. The way the teacher communicates with students significantly affects the students' learning outcome. There are different styles of communication of a teacher. Some speak nervously, fast, slow, or repeatedly. A teacher is urged to speak clearly so the students will easily understand the talk. (5) Conceptualizing supportive class atmosphere. This aspect is central for a teacher to promote good interaction in the educational process. This can be conceptualized by, for example, setting the position of students' chairs, helping students, appreciating students' behavior and opinion. These efforts must be sync with the principle of individuality. (6) Paying attention to the principle of individuality. This element is crucial because students have different skills and characters. That being said, a teacher should not consider that all students are the same. (7) The last characters that should be possessed by a teacher involve open-minded, co-operative, innovative, and willingness to do experiments in teaching and learning activities.

From the above discussion, it can be concluded that teacher's leadership in learning refers to processes of influencing, guiding, directing, driving, and motivating students to follow every instruction by the teacher. This is to accomplish the learning goal.

Another definition of leadership in the learning of the teacher, in this research, refers to the ability of the teacher as a leader in classroom learning to improve students' achievement motivation. This can be done by (1) organizing the learners, (2) stimulating students' interests, (3) promoting fun learning atmosphere, (4) praising students for their success, and (5) creating a competitive and co-operative climate in the class, (6) understanding students' characteristics, (7) encouraging students in learning, and (8) evaluating. 
Creemers and Reezigt (2006, p.231) define classroom climate as a situation in a class, including teacher-student interaction, interaction among students, and interaction with physical elements that influence the students' achievement. Maslowski (as cited in Creemers et al., 2006) states that classroom climate is a set of students' perception regarding mutual relationship in the class. The organization process encompasses several elements, e.g., lesson and learning tasks of the students.

Bloom (as cited in Hadiyanto and Subiyanto, 2003, p.1) explains the term classroom climate as the condition, influence, and stimulation from the outside. This comprises several influences on the students, e.g., physical, social, and intellectual.

Tarmidi (2006, p.3) states that classroom climate is a term describing every situation that is a result between teachers and students interaction. This serves as the characteristic of the class that contributes to the teaching and learning process.

The basic of learning is explained as the interaction between teacher and students or interaction among students. That being said, the success of learning is influenced by some factors, e.g., teacher, student, supporting facilities, and interaction during the learning process.

From the above definitions, classroom climate is defined as a condition that resulted from the interaction between teacher and students in a class that contributes to the process of teaching and learning.

\section{Method}

This study employed a quantitative method with a correlational approach as it is intended to find out whether the tree variables in this study are related to each other. The variables are teacher's leadership in learning $\left(\mathrm{X}_{1}\right)$, classroom climate $\left(\mathrm{X}_{2}\right)$ and students' achievement motivation (Y).

According to Sugiono (2008, p.80) population refers to an area of generalization consisting of the object(s) or subject(s) possessing certain qualities or characteristics that meet the needs of the research. The subject(s) or object(s) are further analyzed prior to coming into a conclusion. In this study, the population involved 400 students in all junior high schools within Limboto.

The sample was selected using the formula by Taro Yamanae and Slovin (as cited in Riduwan, 2012, p.95) as follows:

$$
\begin{array}{cl}
\mathrm{n}=\frac{N}{N \cdot d^{2}+1} & \\
\begin{array}{cl}
\text { Description: } \\
\mathrm{n}
\end{array} & =\text { total of sample } \\
\mathrm{N} & =\text { Number of Population (400 respondents) } \\
\mathrm{d}^{2} & =\text { percentage (set at } 10 \% \text { with the significance level of } 95 \%)
\end{array}
$$

From the above formula, the number of the sample is as follows:

$$
n=\frac{N}{N \cdot d^{2}+1}=\frac{400}{(400) 0.1^{2}+1}=\frac{400}{5}=80 \text { students }
$$

As many as 80 students were selected as the sample since the calculation determines that the number of the sample is $10 \%$ of the total population. The sampling was done using a simple random sampling method.

From the above formula, the number of the sample (grade VIII students) in each selected schools is as follows: 
SMP $1($ School 1$)=125 / 400 \times 80=25=25$ respondents

SMP $2($ School 2$)=175 / 400 \times 80=35=35$ respondents

SMP $3($ School 3$)=175 / 400 \times 80=20=20$ respondents

A validity test was done to ensure the appropriateness of the instrument with the object measured, thus ensuring its accuracy. A Pearson product moment formula was used to examine the validity of the instrument; the formula is as follows:

$$
r_{x y=} \frac{n\left(\sum x y\right)-\left(\sum x\right) \cdot\left(\sum y\right)}{\left.\left.\sqrt{\left(n \sum x^{2}\right)}-\left(\sum x\right)^{2}\right\}\left(n \sum y^{2}\right)-\left(\sum y\right)^{2}\right\}}
$$

Reliability test is a test to determine the reliability of a particular measuring instrument (Suharsimi, 2006, p.178). A reliable instrument signifies that the instrument can be used to collect data. The following formula by Suharsimi (2006, p.171) was used to test the reliability of the instrument in this research.

$$
\boldsymbol{r}_{11}=\left[\frac{k}{(k-1)}\right]\left[1-\frac{\sum \sigma^{2}}{\sigma^{2}}\right]
$$

The following formula was used to test the hypothesis and determine whether or not the data are normally distributed:

$$
\mathrm{X}^{2}=\sum_{i=1}^{n} \frac{(\mathrm{Oi}-\mathrm{Ei})^{2}}{\mathrm{Ei}}
$$

The correlation degree between variable $\mathrm{X}$ and $\mathrm{Y}$ was analyzed for calculation. The correlational coefficient is based on a set of data (xi, yi) and a particular measure (n) is calculated using the formula of correlational coefficient as follows:

$$
\frac{\mathrm{n}\left(\sum \mathrm{XYi}\right)-\left(\sum \mathrm{Xi}\right)\left(\sum \mathrm{Yi}\right)}{\sqrt{\left\{\mathrm{n} \sum \mathrm{Xi}^{2}-\left(\sum \mathrm{Xi}\right)^{2}\right\}}\left\{\mathrm{n} \sum \mathrm{Yi}^{2}-\left(\sum \mathrm{Yi}\right)^{2}\right\}}
$$

Sudjana (2009, p.134) mentions that the Pearson Product Moment (PPM) used in a correlational analysis requires the sample data to be randomly selected (random sampling). The analysis to examine the degree of correlation shown by a correlational coefficient of a causal correlation between variable $\mathrm{X}_{1} \mathrm{~d}$ and $\mathrm{X}_{2}$ and $\mathrm{Y}$ is as follows

$r X_{1} X_{2} Y=\sqrt{\frac{r^{2} x_{1} y+r^{2} x_{2} y-2 \cdot r^{2} x_{1} y \cdot r^{2} x_{2} y \cdot r x_{1} x_{2}}{1-r^{2} x_{1} x_{2}}}$

\section{Results and Discussion}

Learning is an interaction between students and teachers (including learning resources) in an educational environment. Such a process also refers to assistance provided by teachers aiming at transferring knowledge to students. This helps the students to master new skills, shape students' attitude, as well as improving their confidence. In other words, learning is a process that helps the students to learn better. This is a life-long process, regardless of time and space limitation. The term learning is somewhat similar to the term teaching, but it has a different concept or meaning.

Learning is also defined as the empowerment of students' potential and turn it into their competence. This process of empowerment can only be accomplished with people's involvement. Dimyati and Mudjiono (as cited in Sagala, 2011, p.62) point out that learning 
refers to organized activities by a teacher in an instructional design aiming at conceptualizing active learning that emphasizes the provision of learning resources. Further, Act No. 20 of 2003 Considering National Education System explains that learning is a process involving the interaction between students and teachers (including learning resources) in an educational environment.

The result of descriptive analysis on respondents' answer reveals that the most significant frequency is in the class interval 86-91 with the frequency of 23 students. The lowest frequency is in the interval 62-67 with only one student. The variable of teacher's leadership in learning is categorized good with a score of $78.1 \%$. This signifies that teachers in all junior high schools in Limboto Sub-district, Gorontalo Regency possess good quality leadership in training that improves students' engagement during the class and the students' willingness to finish the tasks assigned by the teacher.

Leadership in learning is suitable to be implemented in a school considering the school's main objective to educate students and give the students an opportunity to gain knowledge, skills, and values needed in the future. Such leadership also helps the students to be competent and successfully cope with complex problems in the future.

The result reveals that in the significance level of $95 \%$, the teachers' leadership in learning process positively and significantly contributes to the students' achievement motivation in all junior high schools in Limboto Sub-district, Gorontalo Regency. This demands the contribution and attention of the teacher to improve the students' motivation achievement in the research site. The value of correlational coefficient arrives at 0.637 , meaning that the correlation between the independent and dependent variables is at $63.7 \%$. In conclusion, the variable of teachers' leadership in the learning process has a significant correlation with the variable of students' achievement motivation.

The above results are in line with the opinion by Mulyasa $(2007$, p.156) explaining that leadership in training is crucial for a school as this element significantly contributes to the improvement of students' motivation achievement. This type of leadership can drive and direct all members of a school community to work together for better motivation achievement of the students. In addition, leadership in learning functions to narrow the focus of the school community to the accomplishment of the school's vision and mission. Another consideration is that the purpose of leadership in learning in developing the school community and even promoting the characteristics of learning school. Anwar (1990, p.4) asserts that in learning, a teacher as a leader in the class is responsible for guiding and influencing students to do activities efficiently for a conducive learning atmosphere.

The above result is in line with a study by Abdulah (2013) that the leadership style of a teacher contributes to the achievement motivation of students. In her study, Abdulah points out the better the leadership style, the more improved the students' motivation and vice versa. This is based on the value of coefficient $r^{2}=0.37$, meaning that $37 \%$ of the students' achievement motivation is influenced by the teacher's leadership style, while the remaining $63 \%$ refers to other contributing factors. Such a result further emphasizes the significance of the teacher's leadership style as among the factors that contribute to students' achievement motivation even though this variable only affects $37 \%$ of the students' motivation variable. Nonetheless, this outcome is considered significant statistically.

A study by Ristiandini, however, shows a different result in terms of the percentage of the influence of leadership style on students' learning achievement. Before implementing the treatment of leadership style, the students' learning outcome in subjects, e.g., mathematics, Indonesian language, natural sciences, social sciences, and civic and Pancasila education is represented by the average score of 71.10 . This score is later increased to 75.16 after the 
leadership treatment. The result of a t-test reveals that the $t$ value arrives at -27.936 with sig 0.000 , meaning that sig value $<0.05$. The percentage of the influence of teacher's leadership in learning on students' learning achievement reaches $31.4 \%$. This result confirms that the leadership of the teacher in learning has a positive influence on the learning achievement of the students.

The above discussions reveal that the previous studies have proven the significant correlation between teacher's leadership in learning and students' achievement motivation despite varied results. Therefore, it can be said that the leadership of the teacher contributes to the improvement of achievement motivation.

The result of descriptive analysis on respondents' answer reveals that the most significant frequency is in the class interval 42-44 with the frequency of 24 students. The lowest frequency is in the interval $30-32$ with only two students. The classroom climate variable is categorized good with a score of $72.2 \%$. This result confirms that the classroom climate in all state junior high schools within Limboto Sub-district, Gorontalo Regency helps students in learning and improves their achievement motivation.

In other words, the above result also states that the hypothesis that "classroom climate positively and significantly contributes to the students' achievement motivation in the research site" is accepted. That being said, the schools should be taken into account its classroom climate as the quality classroom can provide all the needs of the students in learning and, therefore, increase their motivation.

The value of correlational coefficient arrives at 0.610 , meaning that the correlation between the independent and dependent variables is at $61.0 \%$. Thereby, the variable of classroom climate has a significant correlation with the variable of students' achievement motivation. Effective learning, without question, results in better students' achievement as the students are able to comprehend the lesson taught by the teacher. This is in line with the argument by Soemoenar (1991) that the classroom atmosphere created by a teacher is among the key to students' success.

Abdulah (2013) also has the same opinion that the classroom climate, among other contributing factors, has a positive contribution to the achievement motivation of the students. In her study, the correlation between those variables is represented by the value of $r^{2} 0.52$ or $52 \%$.

Sudjana (as cited in Hadiyanto, 2009, p.2) shares a similar opinion with the above result. Sudjana explains that some factors determine the quality of learning, e.g., teacher's competency, characteristic(s) of a class (especially the number of the students, classroom climate, facilities and learning resources, and characteristics of the school. Stated in more than 45 studies, Fraser (as cited in Hadiyanto, 2009, p.2) also supports this opinion that there is a positive influence between classroom climate and students' achievement. Studying in conducive atmosphere enables the students to perform better rather than in a situation that does not satisfy the students' needs.

The result of descriptive analysis on respondents' answer reveals that the most significant frequency is in the class interval 60-63 with the frequency of 22 students. The lowest frequency is in the interval 44-47 with six students. The variable of achievement motivation is categorized good with a score of $77.9 \%$. This signifies that effective teachers' leadership in the learning process and classroom climate can raise students' achievement motivation in selected junior high schools in Limboto Sub-district, Gorontalo Regency.

The result reveals that in the significance level of $95 \%$, the teachers' leadership in learning process positively and significantly contributes to the students' achievement motivation in all junior high schools in Limboto Sub-district, Gorontalo Regency. The value of r-count arrives 
at 0.746 . This shows that the correlation between the independent and dependent variables is at $74.6 \%$. In other words, the variable of teachers' leadership in the learning process and classroom climate has a significant correlation with the variable of students' achievement motivation.

Abdulah (2015) shares a similar opinion regarding the above discussion in her study. The study reveals a significant correlation between independent variables and dependent variable represented by the percentage of $52 \%$. This further confirms the correlation between teacher's leadership in learning and classroom climate and students' achievement motivation. In other words, the better the quality of leadership and condition of a class, the more motivated the students to success.

\section{Conclusions}

This research concludes that:

1. Teachers' leadership in learning process positively and significantly contributes to the students' achievement motivation in the research site; this is depicted from its The value of correlational coefficient arrives at 0.637 , In other words, the correlation between the independent and dependent variables is at $63.7 \%$, significantly correlated.

2. Classroom climate positively and significantly contributes to the students' achievement motivation in the research site; this is depicted from its correlational coefficient at 0.610 . This signifies that the correlation between the independent and dependent variables is at $61.0 \%$, significantly correlated.

3. Both teachers' leadership in the learning process and classroom climate positively and significantly contributes to the students' achievement motivation in the research site. The result of the simultaneous correlational calculation reveals that the value of $r$-count arrives at 0.746 . This shows that the correlation between the independent and dependent variables is at $74.6 \%$. In conclusion, the variable of teachers' leadership in the learning process and classroom climate has a significant correlation with the variable of students' achievement motivation.

\section{References}

Anwar, M. I. (2004). Manajemen perlengkapan sekolah teori dan aplikasinya [Management of school facilities: theory and its application]. Jakarta: Bumi Aksara.

Arikunto, S. (2007).Manajemen penelitian [Research management]. Jakarta: Rineka Cipta.

Arikunto, S. (2010). Prosedur penelitian suatu pendekatan praktik [Research procedures, a practical approach]. Jakarta: Rineka Cipta.

Creemers, B. P. M.,\&G. J. Reezigt.(2006). School level condition affecting the effectiveness of instruction. School effectiveness and school improvement.

Danim. S. (2008). Visi baru manajemen sekolah dari unit birokrasi kelembagaan akademik [New vision of school management from the bureaucracy unit of an academic institution]. Jakarta: Bumi Aksara.

Danim. S. (2012). Motivasi kepemimpinan dan efektifitas kelompok [Motivation for leadership and group effectiveness]. Jakarta: Rineka Cipta.

Djamrah \& Zain. (2006). Manajemen sumber daya manusia [Human resource management]. Yogyakarta: Andi.

Edi. S. (2011). Manajemen sumber daya manusia [Human resource management]. Jakarta: Kencana Media Group. 
Gagne, R. M., \& Barliner, R. (2005). Principle of instructional design.New York: Prentice Hall.

Haditono, S. R.(2009). Achievement motivation. Yogyakarta: Gajah Mada.

Haryanto. (2001). Pengembangan kultur sekolah makalah disajikan dalam seminar di UNY [Development of school culture, a paper presented in seminar at UNY].

Kurniaddin, D., \&Imam, M. (2014). Manajemen pendidikan konsep dan prinsip pengelolaan pendidikan [Educational management concepts and principles of education management]. Yogyakarta: Ar-Ruzz Media.

Heekhausen. (2007). The anatomy of achievement.New York: Academy Press.

Lindgren, C. (2006). An introduction to social psychology 2nd Ed. New Delhi:

Wiley Eastern Private Limited.

Martianah, S. M. (1984). Motif sosial remaja Jawa dan keturunan Cina: Suatu studi perbandingan [Social motives of Javanese youth and Chinese breeds: A comparative study]. Yogyakarta: Gadjah Mada Press.

Mc Clelland. (2007). Organization Theory and Design. New York.

Mulyasa, E. (2002). Menjadi guru profesional menciptakan pembelajaran kreatif dan menyenangkan [Becoming a professional teacher: Creating a fun and creative learning]. Bandung: Pt. Remaja Rosdakarya.

Mulyasa, E. (2009). Kurikulum berbasis kompetensi [Competency-based curriculum]. Bandung: Remaja Rosdakarya.

Parson., \&Walker, G. (2001). The Effect of Ethnicity and Gender on Facilitating Intrinsic Motivation during Leisure with a Close Friend.Journal of Leisure Research,40, $290-331$.

Purwanto, N. (2005). Administrasi dan supervisi pendidikan [Educational administration and supervision]. Bandung: Remaja Rosda Karya.

Riduwan. (2003). Dasar-dasar statistik [The basics of statistics]. Bandung: Alfabeta.

Sanjaya. W. (2006). Strategi pembelajaran berorientasi standar proses pendidikan [Education standard-oriented learning strategies]. Jakarta: Prenadamedia Group.

Santrock, J. W. (2007). Perkembangan anak, edisi ke-11 Jilid 1 [Children Development, 11th Ed. Vol. 1].Jakarta:Penerbit Erlangga.

Sardiman. (2012). Interaksi dan motivasi belajar mengajar [Interaction and motivation in teaching and learning]. Jakarta: PT. Raja Grafindo Persada.

Sugiyono. (2013). Metode penelitian pendidikan [Educationalresearch methodology]. Bandung: Afabeta.

Suryosubroto, B. (2002). Proses belajar mengajar di sekolah [Teaching and learning process at school]. Jakarta: Rineka Cipta.

Suwarna. (2006). Interaksi dan motivasi belajar mengajar [Interaction and motivation in teaching and learning]. Jakarta: Raja Grafindo Persada.

Uno, B. H. (2013). Teori motivasi dan pengukurannya [Theory of motivation and its measurement]. Jakarta: PT Bumi Aksara.

Usman, H. (2008). Manajemen teori praktik dan riset pendidikan [Management theory of educational practice and research].Jakarta: Bumi Aksara.

Wahab, A. A. (2011). Anatomi organisasi dan kepemimpinan pendidikan: telaah terhadap organisasi dan pengelolaan organisasi pendidikan [An anatomy of organizational and educational leadership: A review of organization and management of educational organizations]. Bandung: Alfabeta. 